\title{
Avian assemblage along an urban gradient: diversity, abundance and richness
}

\author{
Ghulam Mustafa Rashid ${ }^{1}$, Abida Butt $^{1 *}$, Abdul Qadir $^{2} \&$ Mirza \\ HABIB ALI ${ }^{3}$
}

Received: March 23, 2020 - Revised: June 11, 2020 -Accepted: June 13, 2020

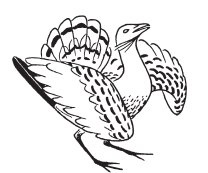

Rashid, G. M., Butt, A., Qadir, A. \& Ali, M. H. 2020. Avian assemblage along an urban gradient: diversity, abundance and richness. - Ornis Hungarica 28(1): 49-64. DOI: 10.2478/ orhu-2020-0004 was studied to explore variations in the avian community dynamics in rural - urban gradient. For this purpose, sampling was done from September 2013 to August 2015. A total of 35 sites, each covering an area of $300 \mathrm{~m}^{2}$ were sampled by using point count method. At each site, randomly three points (minimally $5 \mathrm{~m}$ apart from each other) were selected to study the birds. According to data, species richness $\left(\mathrm{F}_{2,32}=47.18, \mathrm{P}<0.001\right)$ varied significantly along a rural-urban gradient. A significant difference in avian density per sampling site $\left(\mathrm{F}_{2,32}=105.41\right.$, $\mathrm{P}<0.001$ ) was also observed along urbanization gradient. In PE and RU areas, avian assemblages were more diverse than UR areas. Among avian guilds, omnivores were the most abundant in UR while insectivores in PE areas. Frugivores and carnivores were abundant in RU areas. Granivores were recorded in all habitats with similar diversity. A close association was recorded in bird density of RU and PE areas than UR areas. Bird species richness and diversity showed negative correlation with built area and positive correlation with vegetation cover in an area.

Keywords: avian guilds, species richness, abundance, avian diversity, habitat structure, urban (UR), peri-urban (PE), rural (RU)

Összefoglalás Három madárközösség, városi (UR), városhoz közeli (PE) és vidéki (RU) diverzitását és a dinamikáját tanulmányoztuk 2013. szeptember és 2015. augusztus között. Összesen 35, egyenként $300 \mathrm{~m}^{2}$ területen számoltuk össze a madarakat és madárfajokat. Minden mintavételi terület további $50 \mathrm{~m}^{2}$-es részekre lett felosztva. A fajgazdagság $\left(\mathrm{F}_{2,32}=47,18, \mathrm{P}<0,001\right)$ jelentős változatosságot mutatott a vidéki-városi gradiens mentén. A mintaterületenkénti madársürüség szignifikáns különbséget mutatott $\left(\mathrm{F}_{2,32}=105,41, \mathrm{P}<0,01\right)$ a városiasodás mértéke mentén. A városhoz közeli és vidéki területek madárközössége változatosabb, mint a városi. Öt különböző madár-guildet azonosítottunk. A mindenevők voltak a leggyakoribbak a városban, míg a rovarevők nagy abundanciát mutattak a városhoz közeli területeken. A gyümölcsevők és a ragadozók a vidéki területeken voltak a leggyakoribbak. Szignifikáns összefüggés adódott a madársürüség és az élőhely szerkezete között a vidéki és a városhoz közeli területek esetében, mind a klaszter analízis, mind a Sorensen hasonlósági koefficiens alapján. A fajgazdagság és diverzitás negatív összefüggést mutatott az épített területek arányával, de pozitívat a növényborítottsággal.

Kulcsszavak: madár guildek, fajgazdagság, faj abundancia, madár diverzitás, élőhelyszerkezet, városi, városhoz közeli, vidéki

\footnotetext{
${ }^{1}$ Department of Zoology, University of Punjab, Quaid-e Azam Campus, Lahore, Pakistan

${ }^{2}$ College of Earth and Environmental Sciences, University of the Punjab, Lahore, Pakistan

${ }^{3}$ Pakistan Science Foundation, Islamabad, Pakistan

*corresponding author: abidajawed.zool@pu.edu.pk
} 


\section{Introduction}

Urbanization is considered as the leading force behind habitat fragmentation and degradation (Seress \& Liker 2015, Leveau \& Leveau 2016, Hensley 2018) but its consequences on avian biodiversity are studied only sparingly in Pakistan (Joshua \& Ali 2011, Ali et al. 2013, Khan et al. 2014, Abbasi et al. 2015, Ali et al. 2016, Altaf et al. 2018). Urban expansion has impacted local avian species dynamics worldwide (Rottenborn 1999, Melles et al. 2003, White et al. 2005, Chace \& Walsh 2006, Aronson et al. 2014, Peck et al. 2014).

Avian communities respond differently to urban development (Hostetler 2001, Lim \& Sodhi 2004, Ortega-Álvarez \& MacGregor-Fors 2009, Trammell \& Bassett 2012). Their density increases and richness decrease as they approach the urban core. Omnivore fauna is almost similar in urban core throughout the world (McKinney 2008, Garaffa et al. 2009, Dallimer et al. 2012) and holds a few, very abundant species (Bellanthudawa et al. 2019). Urbanization also leads to a numerical increase in exotic species and decrease in native species (McKinney 2006, van Rensburg et al. 2009, Luck \& Smallbone 2010, Sol et al. 2017). Relative contribution of introduced and native species influences the response patterns of the total avian fauna (Hansen \& Urban 1992, Lim \& Sodhi 2004, Villegas \& Garitano-Zavala 2010).

Many studies reported that urbanization is decreasing the diversity of bird species due to loss of habitat. Fernandez-Juricic and Jokimäki (2001) reported that wooded trees in urban areas can increase landscape connectivity by increasing alternative foraging and nesting sites for birds in breeding season. Increased size of parks may enhance diversity and density of birds in urban habitats. The abundance of resident breeding birds is negatively affected by urban sprawl (van Rensburg et al. 2009). The work of van Rensburg et al. (2009) reported that the process of biotic homogenization increase in alien bird species in urban habitat. Parsons et al. (2006) documented that native vegetation in gardens of urban habitats positively influence the density of small birds. In Southeast Asia, heavy losses of native habitat resulted in $13-85 \%$ of decline in biodiversity in the region, including birds (Yap \& Sodhi 2004, Peh 2010). However, in Pakistan a very little work has been done so far. Altaf et al. (2018) recorded avian diversity around river Chanab, Pakistan. They documented decrease in avian diversity from forest habitats to urban habitats. The study showed that bird diversity in urban habitat is related with anthropogenic activities and vegetation cover in the area. Joshua and Ali (2011) reported an increase in abundance of granivorous birds in densely populated areas of Lahore city that have pockets of vegetation Ali et al. (2013) reported that old residential areas of Islamabad city as main nesting and roosting sites of Feral Pigeons (Columba livia domestica). The density of pigeons change with rooting and nesting sites and available food and water sources.

The aim of the study is to analyze the structure of residing and breeding bird community along urbanization gradient with an emphasis to explore effect of urbanization on avian assemblage. The following hypotheses were tested through this study.

1. How much species diversity and relative abundance of avifauna is similar in UR, PE and RU areas?

2. On what landscape components (viz., built area, small vegetation, bushes, woody structure and water bodies/watered soil) avian diversity depends along rural-urban gradient? 


\section{Material and methods}

\section{Study area}

The present study was conducted in Gujranwala district $\left(32.1877^{\circ} \mathrm{N}, 74.1945^{\circ} \mathrm{E}, 226 \mathrm{~m}\right.$ asl) which is the $7^{\text {th }}$ most populous district of Pakistan with a current human population exceeding over two million (Hussain et al. 2012, Minallah et al. 2016, Basit et al. 2018). Climatic conditions highly varied and temperatures above $45^{\circ} \mathrm{C}$ was recorded in summer and close to or below freezing point during winter nights (Mehmood et al. 2017). It is located in the alluvial plains of Indus with the Chenab in north and the Ravi in the south covering an area of $3198 \mathrm{~km}^{2}$. The study area (approximately $226 \mathrm{~km}^{2}$ ) represents a mosaic of urban (49 $\left.\mathrm{km}^{2}\right)$, peri-urban $\left(30 \mathrm{~km}^{2}\right)$ and rural $\left(147 \mathrm{~km}^{2}\right)$ areas.

\section{Sampling strategy}

Based on proportion of built area, the study area was divided into three zones i.e. urban (UR), peri-urban (PE) and rural (RU) following Marzluff and Ewing (2001), Clergeau et al. (2006) and McKinney (2002) using geographic information system (GIS) (Figure 1). In

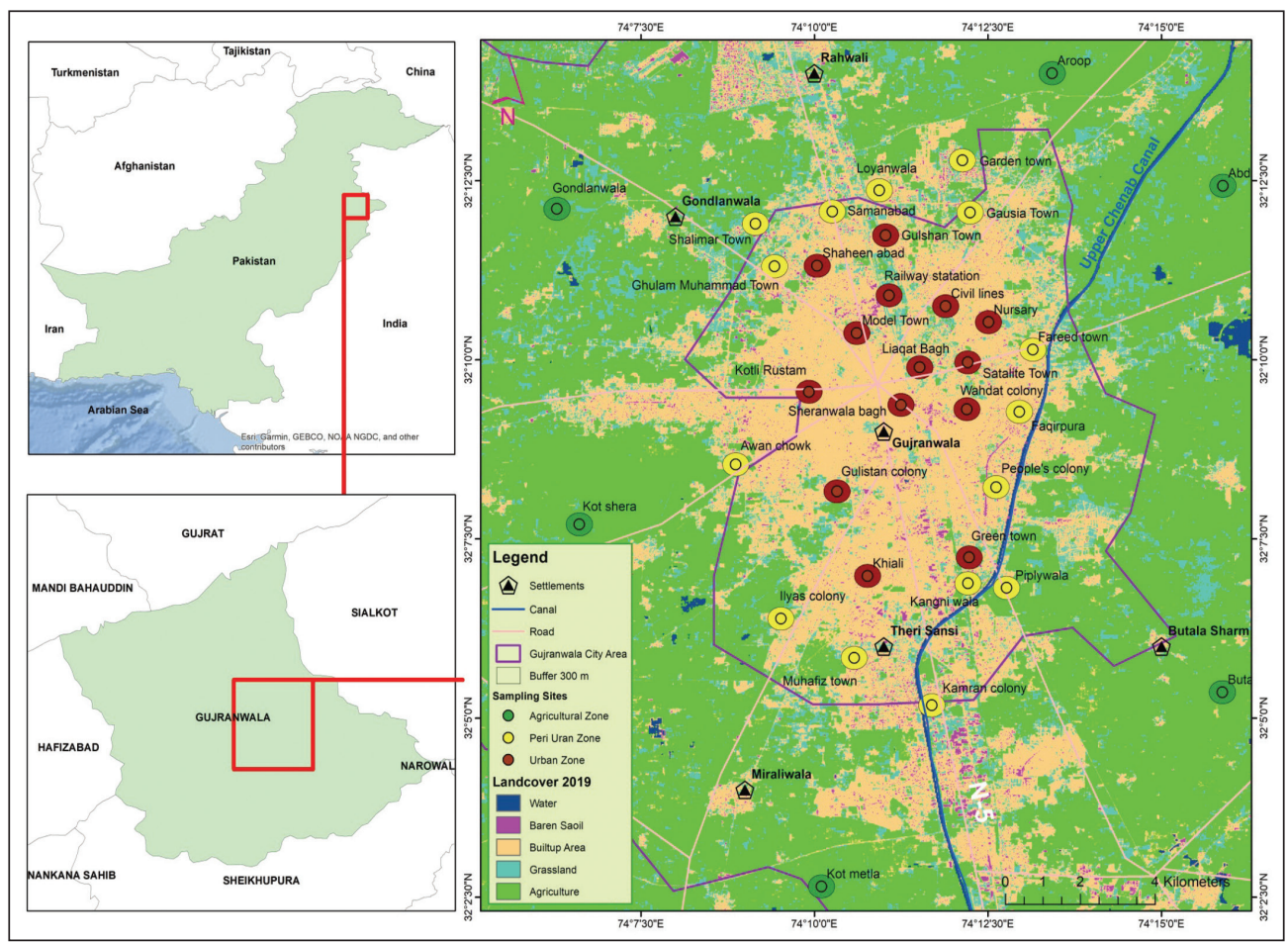

Figure 1. Location of sampling sites with land cover classes in different ecological zones along ruralurban gradient

1.ábra A mintavételi területek elhelyezkedése és felszínborítottságuk a különböző ökológiai zónákban 
each zone, different site each of $300 \mathrm{~m}^{2}$, was selected to study the density and diversity of birds. At each site, the data of residential area, vegetation cover, and water bodies or watered soil was recorded using GIS (Anjum et al. 2016).

Avian diversity and density was recorded from all (UR, PE and RU) sites each month for a period of two years extending from September 2013 to August 2015. A total of 35 study sites were sampled once every month for $10 \mathrm{~min}$. At each site, three points approximately 5 $\mathrm{m}$ apart from each other, were randomly selected for the survey of birds. Surveys were conducted in clear skies avoiding windy or rainy weather in evening (3-4 p.m., until sunset) to collect data of resident bird only. At each study point, birds present within $5 \mathrm{~m}$ radius on the grounds and on plantation were recorded. For this purpose, Olympus $(10 \times 50)$ binocular was also used to see birds present on the tree. High flying individuals were not recorded in the data. For identification Ali and Ripley (1983), Grimmett et al. (2016) and (Davidar et al. 1997) were used as ready reference.

\section{Guild diversity}

All avian species encountered during this study were classified into five guilds viz., granivores, frugivores, carnivores, insectivores and omnivores. Percentage share in the abundance of these guilds was calculated for each ecological zone (Jongman et al. 1995, Fraterrigo \& Wiens 2005).

\section{Data analysis}

Relative abundance of bird species was used to determine basic ordinal scales of abundance (abundant $>7.0$, common 5.1-7.0, frequent 2.1-5.0, uncommon 0.6-2.0 and rare 0.0-0.5) (Aynalem \& Bekele 2008). Rarefaction curve was used to compare species diversity across habitat along the rural-urban gradient. The species richness and species abundance in three zones viz., UR, PE, and RU was plotted. The steeper curves indicated greater diversity in bird communities. The total number of species recorded for each site was considered as species richness due to equal effort of sampling at each site. For diversity, Shannon-Wiener index and for evenness, Pielou J index was calculated for each sampling site (Magurran 1988). Sorensen similarity index was applied to compare habitats on the bases of abundance data. One way ANOVA with Tukey post-hoc test was used to compare the abundance of birds in each area.

Cluster Analysis (UPGMA) was used to reveal the similarity in bird composition between different areas (Kent \& Coker 1992). Canonical Correspondence analysis (CCA) revealed the association of bird species with different landscape classes along the rural urban gradient (Melles et al. 2003). For UPGMA and CCA, bird species that have relative abundance < 2.00 in overall abundance data per sampling site were not included in the analysis and considered as rare species. 


\section{Results}

\section{Diversity abundance and richness of the avian fauna of the three zones}

To study avian diversity, 35 sites (14 UR, 15 PE and 6 RU) were sampled for two years (Table 1, Figure 1). A total of 7891 birds belonging to 30 species were observed along the rural-urban gradient. Avian density was highest in RU than $\mathrm{UR}$ and PE areas $\left(\mathrm{F}_{2,32}=21.41\right.$, $\mathrm{P}=0.001$ ) (Table 2). However, no difference was recorded in the bird density of UR and PE areas. Four abundant species viz., Pycnonotus cafer, Corvus splendens, Acridotheres tristis, and Passer domesticus accounted for $52.08 \%$ of total density (Figure 2). The highest species richness was recorded in RU areas (30 species) followed by PE (24) and UR (14) areas. Out of thirty species, 14 were present in all three areas viz., UR, PE and RU but differ in their densities. Rarefaction accumulation cure of overall bird species showed sufficient sampling in all studied areas and significantly low richness in UR areas than PE and RU areas $\left(\mathrm{F}_{2,32}=47.18, \mathrm{P}=0.001\right)$ (Figure 3). According to Sorensen coefficient UR and PE areas show $74 \%, \mathrm{PE}$ and RU areas $85 \%$ and UR and RU areas $64 \%$ similarity in bird species. The avian diversity was highest in $\mathrm{RU}$ and lowest in $\mathrm{UR}$ areas $\left(\mathrm{F}_{2,32}=32.57, \mathrm{P}=0.001\right)$. Species evenness in $\mathrm{UR}$ and $\mathrm{PE}$ was significantly higher than $\mathrm{RU}$ areas $\left(\mathrm{F}_{2,32}=10.15, \mathrm{P}=0.001\right)$.

\section{Avian community structure (guild)}

A total of five feeding guilds of avian species were recorded in the data i.e., granivores, frugivores, insectivores, carnivores and omnivores. Among avian guilds, omnivores were the most abundant in UR while insectivores in PE areas. Frugivores and carnivores were abundant in RU areas. Granivores were recorded in all habitats with similar diversity. The highest percentage of carnivorous birds in RU areas indicated their association with the availability of a variety of insect prey items in croplands (Figure 4).

\section{Impact of landscape}

The average composition of all the areas is given in Table 3. Results showed the highest percentage of the residential area in UR, low vegetation in RU and woody plants in PE. A slight difference in the percentage of shrub cover was observed in PE and RU. The highest percentage of water bodies was observed in RU.

A negative correlation of bird diversity and residential area $\left(\mathrm{km}^{2}\right)\left(\mathrm{R}^{2}=0.38, \mathrm{~F}_{1,34}=20.34\right.$, $\mathrm{P}<0.001)$ and positive correlation in bird diversity and small vegetation $\left(\mathrm{R}^{2}=0.44, \mathrm{~F}_{1}\right.$, $\left.{ }_{34}=26.03, \mathrm{P}<0.001\right)$ was recorded along rural urban gradient. However, species richness and diversity did not show any relationship with woody tree cover $\left(\mathrm{km}^{2}\right)$, bush cover and water bodies (Figure 5).

Cluster analysis depicted that on the basis of species abundance, RU and PE areas showed a close relationship with each other than UR areas (Figure 6). The canonical correspondence analysis (CCA) explained the association of dominant bird species with different components of landscape viz., residential area, Low vegetation cover, woody plants, shrubs 
Table 1. Bird species richness (S) and abundance (N) for various study sites

1. táblázat Fajgazdagság (S) és abundancia (N) a különböző vizsgálati területeken

\begin{tabular}{|c|c|c|c|c|}
\hline Site No. & Sites & Location of site & $\mathbf{S}$ & $\mathbf{N}$ \\
\hline 1 & Civil lines & Urban Zone & 14 & 204 \\
\hline 2 & Gulshan Town & Urban Zone & 13 & 208 \\
\hline 3 & Model Town & Urban Zone & 14 & 315 \\
\hline 4 & Nursary & Urban Zone & 13 & 182 \\
\hline 5 & Railway station & Urban Zone & 13 & 272 \\
\hline 6 & Satalite Town & Urban Zone & 12 & 328 \\
\hline 7 & Sheranwala Bagh & Urban Zone & 13 & 213 \\
\hline 8 & Liaqat Bagh & Urban Zone & 11 & 140 \\
\hline 9 & Green town & Urban Zone & 12 & 97 \\
\hline 10 & Kotli Rustam & Urban Zone & 9 & 111 \\
\hline 11 & Khiali & Urban Zone & 13 & 92 \\
\hline 12 & Shaheen abad & Urban Zone & 14 & 136 \\
\hline 13 & Gulistan colony & Urban Zone & 13 & 128 \\
\hline 14 & Wahdat colony & Urban Zone & 12 & 262 \\
\hline 15 & Awan chowk & Peri-urban Zone & 13 & 82 \\
\hline 16 & Loyanwala & Peri-urban Zone & 16 & 102 \\
\hline 17 & Ghulam Muhammad Town & Peri-urban Zone & 16 & 67 \\
\hline 18 & Gausia Town & Peri-urban Zone & 10 & 52 \\
\hline 19 & Kangni wala & Peri-urban Zone & 15 & 122 \\
\hline 20 & Piplywala & Peri-urban Zone & 15 & 121 \\
\hline 21 & Ilyas colony & Peri-urban Zone & 11 & 63 \\
\hline 22 & Kamran colony & Peri-urban Zone & 12 & 75 \\
\hline 23 & Garden town & Peri-urban Zone & 22 & 341 \\
\hline 24 & People's colony & Peri-urban Zone & 18 & 352 \\
\hline 25 & Shalimar Town & Peri-urban Zone & 20 & 251 \\
\hline 26 & Muhafiz Town & Peri-urban Zone & 22 & 331 \\
\hline 27 & Fareed town & Peri-urban Zone & 20 & 132 \\
\hline 28 & Faqirpura & Peri-urban Zone & 15 & 139 \\
\hline 29 & Samanabad & Peri-urban Zone & 14 & 129 \\
\hline 30 & Gondla wala & Agriculture Zone & 24 & 325 \\
\hline 31 & Aroop & Agriculture Zone & 26 & 443 \\
\hline 32 & Kot shera & Agriculture Zone & 28 & 539 \\
\hline 33 & Butala sharm Singh & Agriculture Zone & 28 & 669 \\
\hline 34 & Abdal & Agriculture Zone & 23 & 382 \\
\hline 35 & Kotmetla & Agriculture Zone & 26 & 425 \\
\hline
\end{tabular}


Table 2. Ordinal scale of avian relative abundance per sampling site of study

2. táblázat A madarak relatív abundanciájának rangskálája az egyes mintavételi területeken UR városi, $\mathrm{PE}$ - városhoz közeli, RU - vidéki

\begin{tabular}{|c|c|c|c|c|c|c|}
\hline Bird species & UR/site & PE/site & RU/site & $\mathbf{N}$ & RA & Ordinal scale \\
\hline Vanellus indicus & 0 & 1 & 10 & 11 & 1.35 & Uncommon \\
\hline Columba livia & 19 & 6 & 5 & 30 & 3.67 & Frequent \\
\hline Psittacula krameri & 2 & 5 & 16 & 23 & 2.83 & Frequent \\
\hline Athene brama & 0 & 0 & 2 & 2 & 0.28 & Rare \\
\hline Apus apus & 0 & 2 & 3 & 5 & 0.64 & Uncommon \\
\hline Hylcyon smymensis & 0 & 0 & 9 & 9 & 1.06 & Uncommon \\
\hline Upupa epops & 0 & 1 & 0 & 1 & 0.18 & Rare \\
\hline Motacilla alba & 6 & 7 & 28 & 41 & 5.01 & Common \\
\hline Coracina melaschistos & 0 & 2 & 2 & 4 & 0.49 & Rare \\
\hline Pycnonotus cafer & 12 & 12 & 43 & 67 & 8.25 & Abundant \\
\hline Dicrurus macrocercus & 5 & 6 & 14 & 25 & 3.11 & Frequent \\
\hline Corvus splendens & 48 & 17 & 30 & 95 & 11.66 & Abundant \\
\hline Acridotheres ginginianus & 16 & 5 & 5 & 26 & 3.18 & Frequent \\
\hline Acridotheres tristis & 15 & 20 & 86 & 121 & 14.83 & Abundant \\
\hline Passer domesticus & 19 & 28 & 95 & 142 & 17.34 & Abundant \\
\hline Spilopelia senegalensis & 6 & 11 & 15 & 32 & 3.88 & Frequent \\
\hline Milvus migrans & 32 & 7 & 12 & 51 & 6.27 & Common \\
\hline Centropus sinensis & 0 & 0 & 3 & 3 & 0.37 & Rare \\
\hline Cinnyris asiaticus & 0 & 0 & 5 & 5 & 0.61 & Uncommon \\
\hline Bubulcus ibis & 0 & 6 & 22 & 28 & 3.41 & Frequent \\
\hline Ardeola grayii & 0 & 1 & 4 & 5 & 0.56 & Uncommon \\
\hline Streptopelia orientalis & 0 & 1 & 4 & 5 & 0.64 & Uncommon \\
\hline Riparia riparia & 4 & 7 & 6 & 17 & 2.07 & Frequent \\
\hline Cercomela fusca & 0 & 1 & 10 & 11 & 1.33 & Uncommon \\
\hline Turdus merula & 0 & 2 & 1 & 3 & 0.31 & Rare \\
\hline Turdoides striata & 3 & 3 & 16 & 22 & 2.75 & Frequent \\
\hline Dinopium benghalense & 0 & 0 & 2 & 2 & 0.27 & Rare \\
\hline Egretta garzetta & 0 & 0 & 3 & 3 & 0.37 & Rare \\
\hline Merops orientalis & 6 & 6 & 11 & 23 & 2.84 & Uncommon \\
\hline \multirow[t]{2}{*}{ Gracupica contra } & 0 & 1 & 2 & 4 & 0.44 & Rare \\
\hline & 192 & 157 & 463 & 817 & & \\
\hline
\end{tabular}




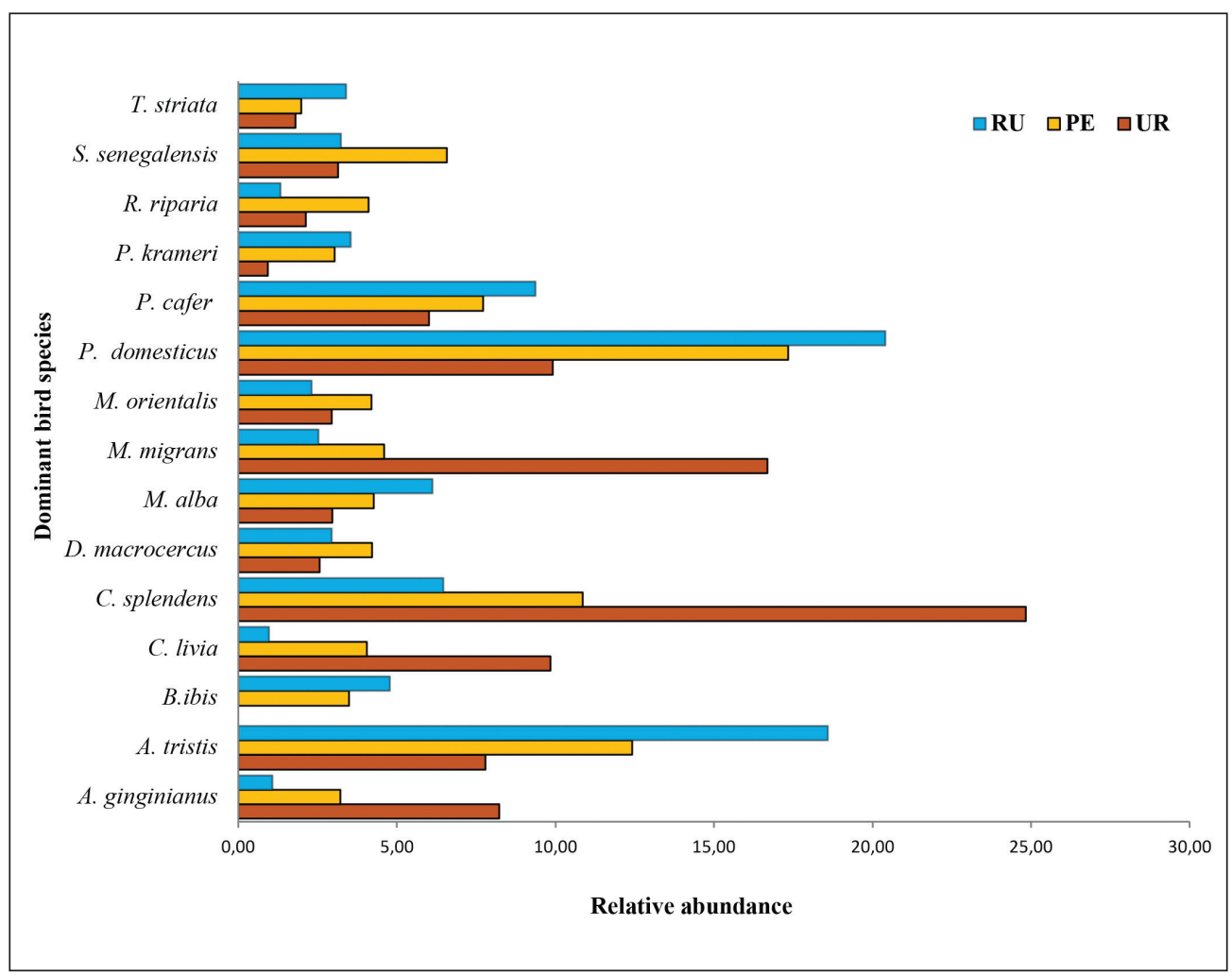

Figure 2. Variations in relative abundance per sampling site of bird species (excluding $<2.00$ of relative abundance) in different habitats along urban gradient

2. ábra A madárfajok relatív abundanciájának változatossága mintaterületenként a különböző élőhelyeken (a 2-nél kisebb relatív abundanciájú fajok kivételével). UR - városi, PE városhoz közeli, RU - vidéki

Table 3. Landscape classification in $300 \mathrm{~m}^{2}$ of circle area at each sampling site along rural-urban gradient

3. táblázat A területborítottság osztályozása a 300 m²-es mintaterületeken. UR - városi, PE - városhoz közeli, RU - vidéki

\begin{tabular}{|c|c|c|c|c|c|c|c|c|c|}
\hline \multirow[b]{2}{*}{$\begin{array}{l}\text { Landscape } \\
\text { classes }\end{array}$} & \multicolumn{3}{|c|}{ UR $(n=14)$} & \multicolumn{3}{|c|}{ PE $(n=15)$} & \multicolumn{3}{|c|}{$R U(n=6)$} \\
\hline & $\begin{array}{c}\text { Av. } \\
\text { Area } \\
\left(\mathrm{Km}^{2}\right)\end{array}$ & SD & $\begin{array}{c}\text { Area } \\
\% \text { age } \\
\left(\mathrm{Km}^{2}\right)\end{array}$ & $\begin{array}{c}\text { Av. } \\
\text { Area } \\
\left(\mathrm{Km}^{2}\right)\end{array}$ & SD & $\begin{array}{c}\text { Area } \\
\text { \%age } \\
\left(\mathrm{Km}^{2}\right)\end{array}$ & $\begin{array}{c}\text { Av. } \\
\text { Area } \\
\mathrm{Km}^{2} \text { ) }\end{array}$ & SD & $\begin{array}{r}\text { Area } \\
\text { \%age } \\
\left(\mathrm{Km}^{2}\right)\end{array}$ \\
\hline Residential area & 207.48 & 36.27 & 73.42 & 109.28 & 8.23 & 38.67 & 20.67 & 3.42 & 7.31 \\
\hline Low vegetation & 45.59 & 24.42 & 16.13 & 85.82 & 14.94 & 30.37 & 217.43 & 6.07 & 76.94 \\
\hline Woody plants & 5.94 & 4.79 & 2.10 & 19.03 & 14.63 & 6.73 & 4.45 & 1.20 & 1.57 \\
\hline Shrubs & 22.25 & 17.10 & 7.87 & 59.56 & 20.10 & 21.08 & 34.50 & 4.39 & 12.21 \\
\hline $\begin{array}{l}\text { Water body or } \\
\text { Watered Soil }\end{array}$ & 1.33 & 1.66 & 0.47 & 8.91 & 7.60 & 3.15 & 5.55 & 0.66 & 1.96 \\
\hline
\end{tabular}




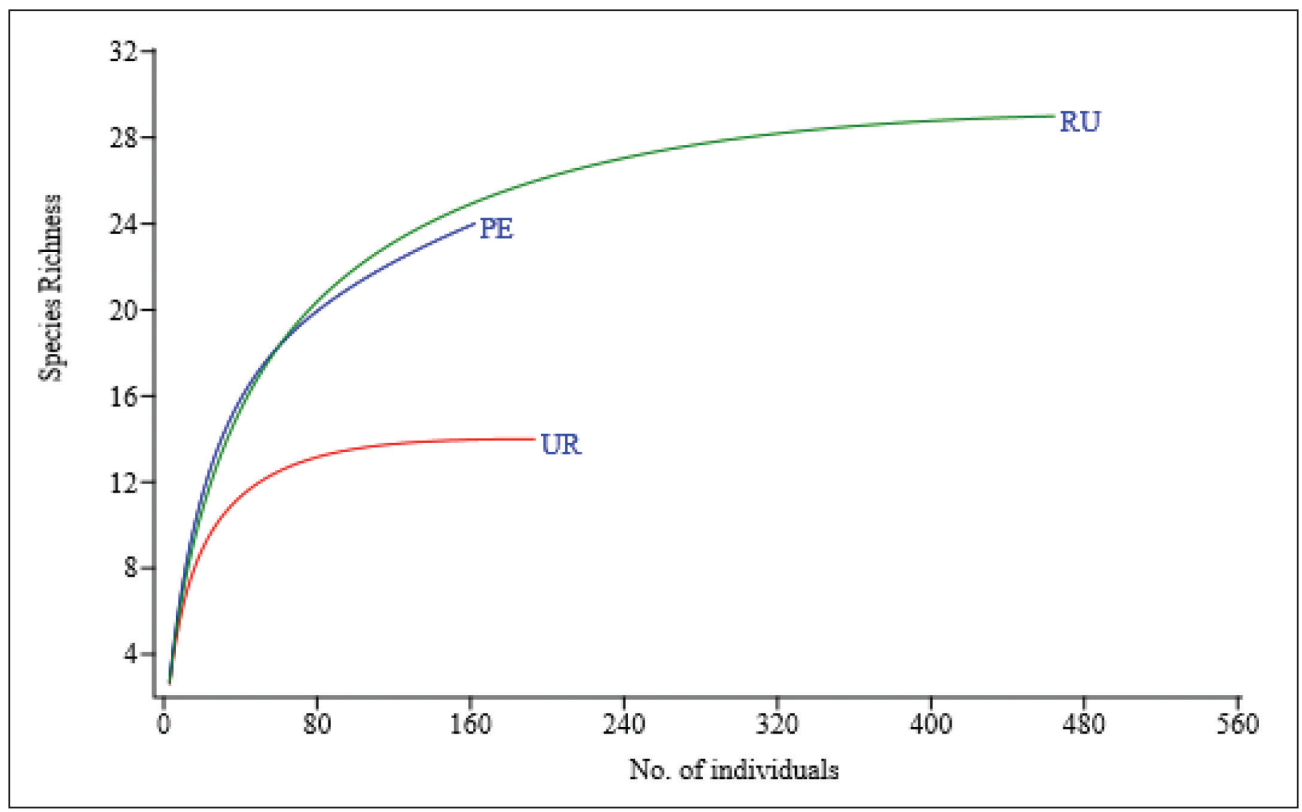

Figure 3. Rarefaction curve showing bird species richness along urban gradient on the basis of the number of individuals / sampling site

3. ábra A fajgazdagság ritkulási görbéje a mintavételi területek egyedszáma alapján. UR - városi, PE - városhoz közeli, RU - vidéki

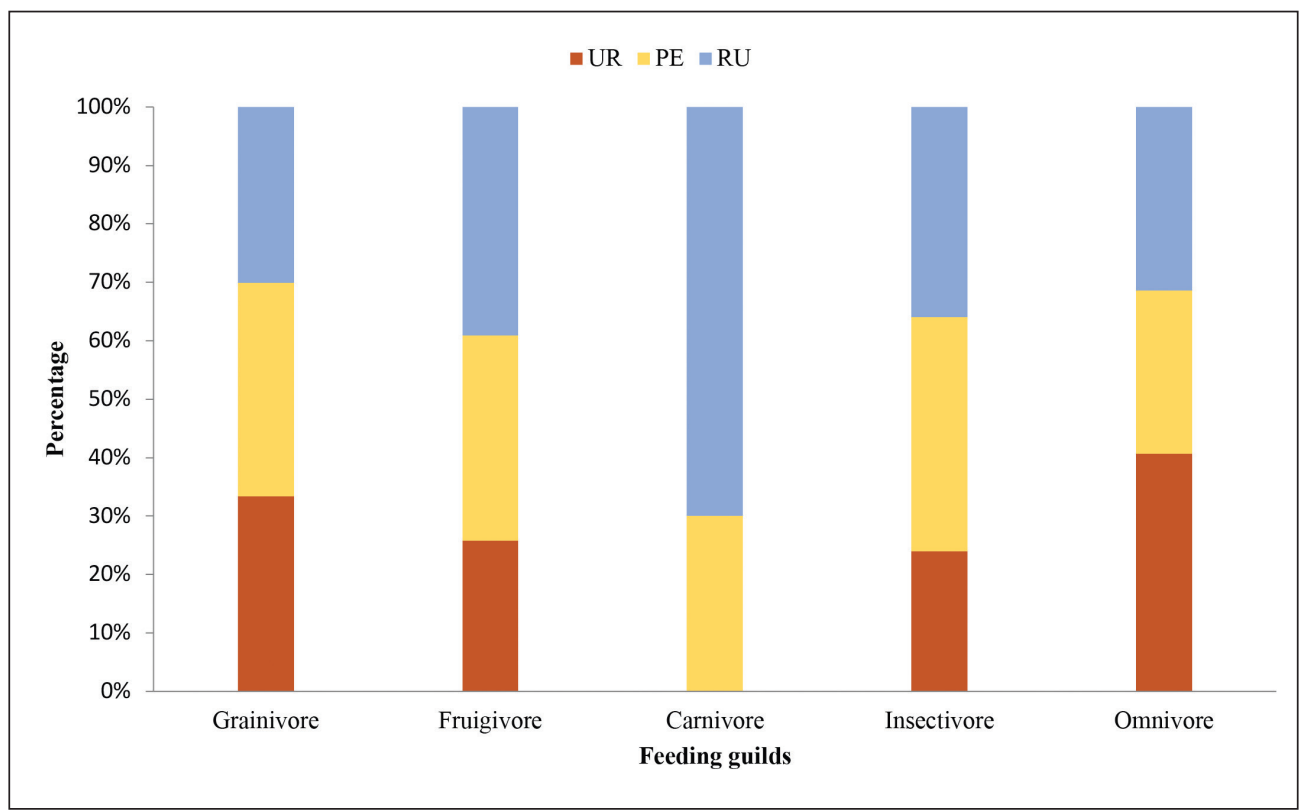

Figure 4. Percentage share of different feeding guilds of birds along urban gradient on overall data 4.ábra A különböző táplálkozási guildek százalékos megoszlása a teljes adatsor alapján. UR városi, $\mathrm{PE}$ - városhoz közeli, RU - vidéki 


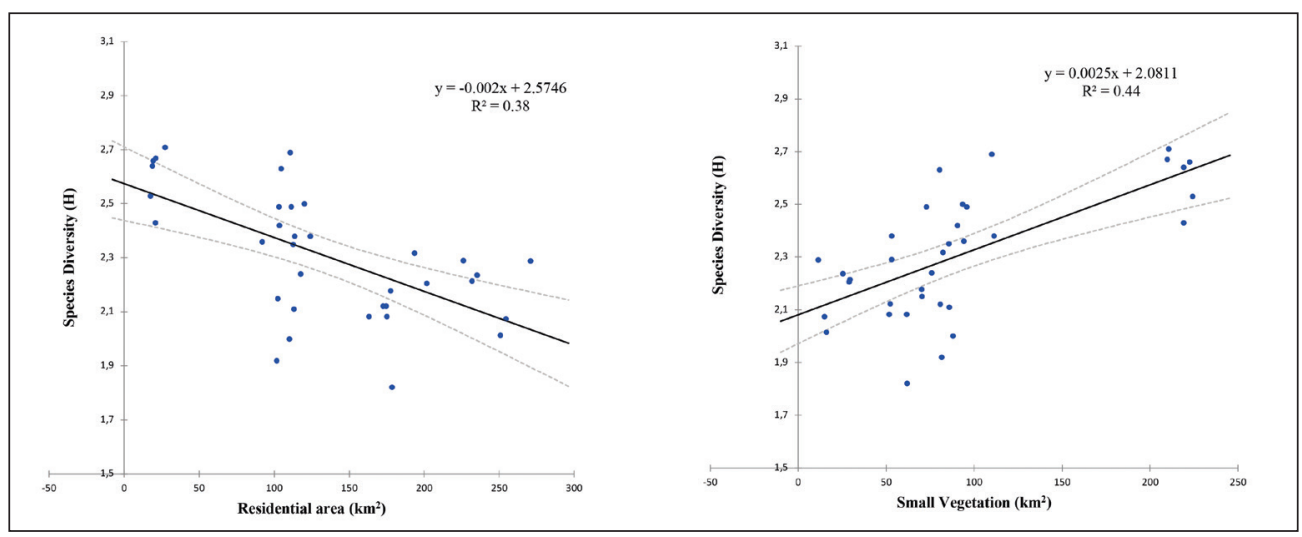

Figure 5. Regression model showing relationship between bird diversity and residential area and small vegetation

5. ábra Regressziós modellek illeszkedése a fajgazdagság és változatosság összefüggésére a különböző vegetáció borítottságú területekkel

and water bodies along a rural-urban gradient. The urban birds viz., Columba livia domestica, Acridotheres ginginianus, Corvus splendens and Milvus migrans showed association with residential areas. Three bird species viz., Merops orientalis, Spilopelia senegalensis and Riparia riparia showed a relationship with moderate residential area and woody plantation. Biplot depicted that Psittacula krameri, Dicrurus macrocercus and Passer domesti-

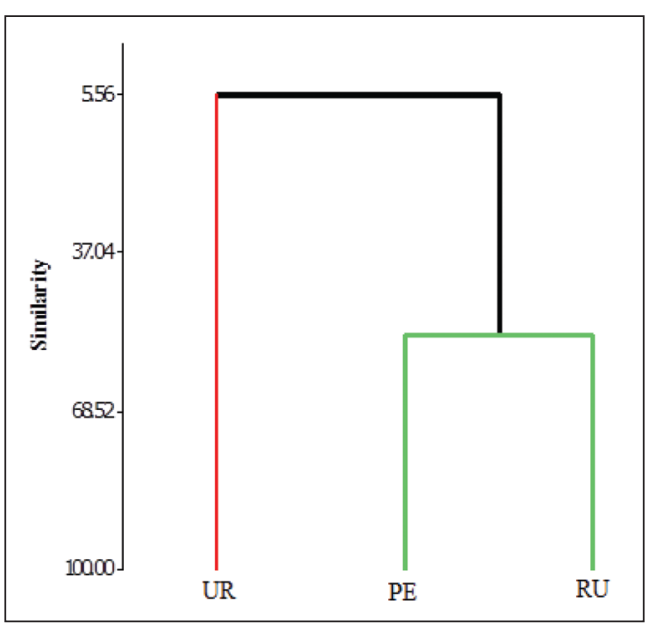

Figure 6. Dendrogram (UPGMA, average linkage between groups) based on Euclidean distances between sites showing UR, PE and RU clusters separately with respect to bird species diversity

6. ábra Euklidészi távolságon alapuló dendrogram a madarak fajgazdagsága közötti hasonlóság értékelésére. UR - városi, PE - városhoz közeli, RU - vidéki cus showed relationship with shrubby and low vegetation cover. Low vegetation cover seemed to be a good habitat for bird species viz., Pycnonotus cafer, Motacilla alba, Acridotheres tristis and Bubulcus ibis with cropland habitat associated with water bodies (Figure 7).

\section{Discussion}

The present research supported our first hypothesis proposing significant variations in density along rural-urban gradient because of variable response of birds towards increasing urbanization. The density of common birds which can find food in anthropogenic resources was highest in UR than $\mathrm{PE}$ and RU areas (Beissinger \& Osborne 1982). However, the bird diversity and richness was least in UR areas. Bird communities were evenly distributed in UR than 


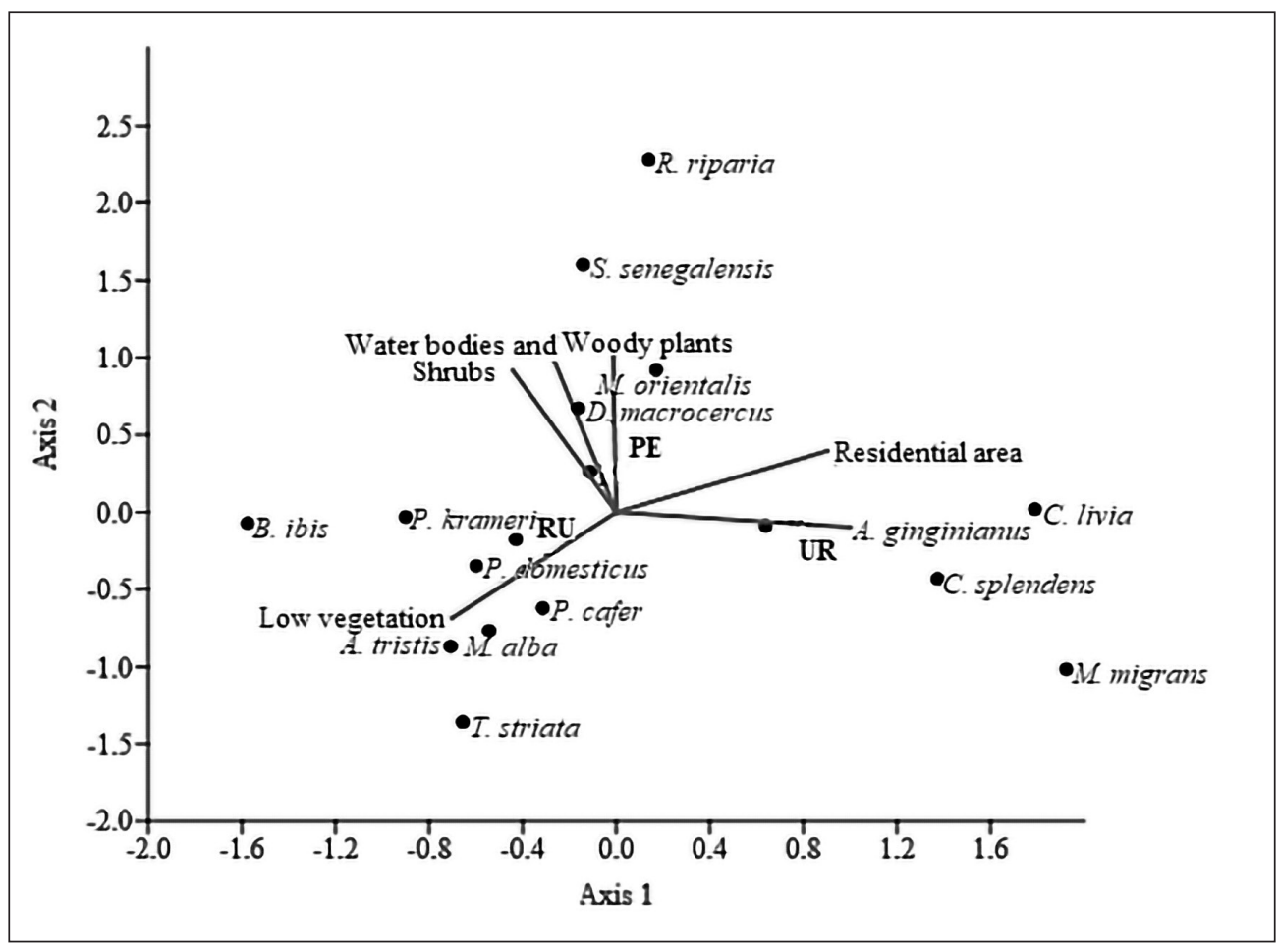

Figure 7. Triplot showing association of dominant bird species with different landscape class along rural- urban gradient

7. ábra A domináns madárfajok és a különböző vegetáció borítottságú területek összefüggése. UR - városi, $\mathrm{PE}$ - városhoz közeli, RU - vidéki

adjoining areas. These findings were in line with the study of Marzluff and Ewing (2001). Blair (2001) also supported the evidence that avian diversity and richness declined as developments proceeded along the rural-urban gradient. Diversity and richness of bird species also have shown a positive relationship with the diversity of trees and shrubs in all habitats.

The avian community structure showed variation along the rural-urban gradient. The analysis of the functional group illustrated resource based distribution of avian communities along a rural-urban gradient. The functional groups viz., frugivores and carnivores dominated in the rural areas which provide higher resource availability, e.g. trees and open areas as compared to urban areas. Rural communities were more evenly distributed as compared to urban areas, which had high dominance of omnivorous species like house crows and common myna. Whereas, urban areas corroborate more omnivore birds (Emlen 1974, Lancaster \& Rees 1979, Beissinger \& Osborne 1982, Mills et al. 1989, Kluza et al. 2000, Fraterrigo \& Wiens 2005, Chace \& Walsh 2006). Expectedly again, the percentages of omnivores abundances were found to be higher due to their close association with residential areas (Fraterrigo \& Wiens 2005, Chiari et al. 2010).

The present study analyzed that avian community varied with variations in land cover classes viz., residential area, small vegetation, woody trees / bushes. Chace and Walsh 
(2006) and Friesen (1998) analyzed impacts of urbanization on structure and composition of avifauna. The evidences supported that increasing structural complexity in habitat structure provided larger degrees of heterogeneity that enables birds to occupy more niches (Poulsen 2002, Machtans \& Latour 2003, Loyola \& Martins 2008, Shochat et al. 2010). The studies emphasized that $C$. splendens and M. migrans had shown association with UR and PE areas. These areas provided sufficient roosting and foraging sites due to natural and anthropogenic sources (Sergio et al. 2003). Many studies showed that these birds are attracted towards public and commercial buildings because of availability of food from anthropogenic source (Rajashekara \& Venkatesha 2014, Manjula et al. 2015, Pattnaik et al. 2016, Katuwal et al. 2018). A. ginginanus primarily prefers farmland habitat that is adapted to urban habitat due to behaviorally flexible foraging habits (Kler 2009). The highest adaptability potential of $C$. livia domestica was observed among invasive urban bird species. This bird was primarily an inhabitant of cliffs while urban area cliffs of building structures provide a substitute of natural cliffs (Tiwary \& Urfi 2016).

Nearly $50 \%$ of the avian population of PE was composed of just two bird species viz., $C$. splendens and $P$. domesticus. In this regard, urban adopters (D. macrocercus, N. murina, $M$. orientalis) were actually inhabitants of PE but had shown tendency to move towards UR. The present data depicted a strong association between $D$. macrocercus and S. senegalensis in PE. It is worth mentioning here that PE acts as a transitional zone which contains a mixed avian assemblage of both habitats of UR and RU (Dearborn \& Kark 2010). Main roosting sites for D. macrocercus in urban area were electric wires, cables, lightning pools, and human source provide them a variety of food items (Sekercioglu 2012).

Species, such as $P$. domesticus, $A$. tristis and $P$. cafer represented $56 \%$ of avian assemblage associated with RU. Granivores get a maximum opportunity of grain food from agriculture habitat but have shown the tendency of adaptability towards UR. Peacock et al. (2007) reported that these birds has adaptability potential for UR because buildings can provide nesting/roosting sites and human resources provide a variety of food items. High density of $P$. krameri in maize and cereal crops in agriculture habitat has been reported (Khan et al. 2004). The high density and diversity of B. ibis was recorded near the water bodies (Changder et al. 2015).

This study showed response of birds to resource availability at various levels of urban development. It will help to explore the suitable conditions for wildlife in urban areas. In this connection, restoration of urban areas of vegetation will definitely help in conservation of avian fauna in urban habitat.

\section{Conclusions}

Avian assemblage has also shown pronounced variations in abundance and richness along the rural-urban gradient. It is noteworthy that the proportion of non-native species (urban exploiters) becomes more common towards the urban core. This research indicated that residential area provided roosting and nesting sites and organic waste as food from anthropo-

genic source to these birds. It could be inferred that human solid waste could be one of the 
major sources of attraction for urban birds. So, proper management of city solid waste material will be helpful in bringing back native bird species. Urban adapter birds mainly adapted to city outskirts where extensive re-vegetation facilitate the restoration of ecological succession. The present study provides public biodiversity education that could be effective in promoting an understanding of concept such as "ecological succession" and role of different landscape classification in promoting native avian diversity along a rural-urban gradient of Gujranwala city (Punjab: Pakistan).

\section{References}

Abbasi, N. A., Khan, M. U., Jaspers, V. L. B., Chaudhry, M. J. I. \& Malik, R. N. 2015. Spatial and interspecific variation of accumulated trace metals between remote and urbane dwelling birds of Pakistan. - Ecotoxicology and environmental safety 113(2): 79-286. DOI: 10.1016/j.ecoenv.2014.11.034

Ali, A., Altaf, M. \& Khan, M. S. H. 2016. Winter survey of birds at Keti Bunder, district Thatha, Pakistan. - Punjab University Journal of Zoology 31(2): 3-208.

Ali, S. \& Ripley, S. D. 1983. Handbook of the birds of India and Pakistan. Compact edition. - Oxford University Press, New Delhi and Oxford

Ali, S., Rakha, B. A., Hussain, I., Nadeem, M. S. \& Rafique, M. 2013. Ecology of Feral Pigeon (Columba livia) in urban areas of Rawalpindi/Islamabad, Pakistan. - Pakistan Journal of Zoology 45(5): 1229-1234.

Altaf, M., Javid, A., Khan, A. M., Khan, M., Umair, M. \& Ali, Z. 2018. Anthropogenic impact on the distribution of the birds in the tropical thorn forest, Punjab, Pakistan. - Journal of Asia-Pacific Biodiversity 11(2): 229236. DOI: 10.1016/j.japb.2018.03.001

Anjum, W., Ahmad, S., Sanaullah, M., Majid, Z. \& Mirza, K. 2016. Geographic information system and modeling approach for groundwater systems of Rechna Doab, Pakistan. - Pakistan Journal of Science 68(4): $470-476$.

Aronson, M. F., La Sorte, F. A., Nilon, C. H., Katti, M., Goddard, M. A., Lepczyk, C. A., Warren, P. S., Williams, N. S., Cilliers, S. \& Clarkson, B. 2014. A global analysis of the impacts of urbanization on bird and plant diversity reveals key anthropogenic drivers. - Proceedings of the Royal Society B: Biological Sciences 281(1780): 201-330. DOI: 10.1098/rspb.2013.3330

Aynalem, S. \& Bekele, A. 2008. Species composition, relative abundance and distribution of bird fauna of riverine and wetland habitats of Infranz and Yiganda at southern tip of Lake Tana, Ethiopia. - Tropical Ecology 49(2): 199-209.

Beissinger, S. R. \& Osborne, D. R. 1982. Effects of urbanization on avian community organization. - The Condor 84(1): 75-83. DOI: $10.2307 / 1367825$.

Bellanthudawa, B., Nawalage, N., Subanky, S., Panagoda, P., Weerasinghe, H., Tharaka, L., Handapangoda, H., Silva, H., Dissanayake, D. \& Abeywickrama, M. 2019. Composition and diversity variation of avifauna, along different vegetative habitat types in a human-modified area, University of Kelaniya, Sri Lanka. - International Journal of Zoology, pp. 1-16. DOI: 10.1155/2019/9727609

Blair, R. B. 2001. Birds and butterflies along urban gradients in two ecoregions of the United States: is urbanization creating a homogeneous fauna? - Biotic Homogenization, Springer, pp. 33-56. DOI: 10.1007/978-14615-1261-5_3

Chace, J. F. \& Walsh, J. J. 2006. Urban effects on native avifauna: a review. - Landscape and Urban Planning 74(1): 46-69. DOI: 10.1016/j.landurbplan.2004.08.007.

Changder, S., Adhurya, S., Roy, U. S. \& Banerjee, M. 2015. A report on midwinter bird diversity from Mangalajodi Wetland, Odisha. - ZOO's Print Journal 30(12): 1-5.

Chiari, C., Dinetti, M., Licciardello, C., Licitra, G. \& Pautasso, M. 2010. Urbanization and the more-individuals hypothesis. - Journal of Animal Ecology 79(2): 366-371. DOI: 10.1111/j.1365-2656.2009.01631.x.

Clergeau, P., Jokimäki, J. \& Snep, R. 2006. Using hierarchical levels for urban ecology. - Trends in Ecology \& Evolution 21(12): 660-661. DOI: 10.1016/j.tree.2006.09.006

Dallimer, M., Rouquette, J. R., Skinner, A. M., Armsworth, P. R., Maltby, L. M., Warren, P. H. \& Gaston, K. J. 2012. Contrasting patterns in species richness of birds, butterflies and plants along riparian corridors in an urban landscape. - Diversity and Distributions 18(8): 742-753. DOI: 10.1111/j.1472-4642.2012.00891.x 
Davidar, P., Yoganand, T., Ganesh, T. \& Joshi, N. 1997. An assessment of common and rare forest bird species of the Andaman Islands. - Forktail 12: 135-142. DOI: 10.1046/j.1365-2699.2001.00584.x

Dearborn, D. C. \& Kark, S. 2010. Motivations for conserving urban biodiversity. - Conservation Biology 24(2): 432-440. DOI: 10.1111/j.1523-1739.2009.01328.x.

Emlen, J. T. 1974. An urban bird community in Tucson, Arizona: derivation, structure, regulation. - The Condor 76(2): 184-197. DOI: 10.2307/1366729

Fernandez-Juricic, E. \& Jokimäki, J. 2001. A habitat island approach to conserving birds in urban landscapes: case studies from southern and northern Europe. - Biodiversity \& Conservation 10(12): 2023-2043. DOI: 10.1023/A:1013133308987

Fraterrigo, J. M. \& Wiens, J. A. 2005. Bird communities of the Colorado Rocky Mountains along a gradient of exurban development. - Landscape and Urban Planning 71(2-4): 263-275. DOI: 10.1016/j.landurbplan.2004.03.008

Friesen, L. 1998. Impacts of urbanization on plant and bird communities in forest ecosystems. - The Forestry Chronicle 74(6): 855-860. DOI: 10.5558/tfc74855-6

Garaffa, P. I., Filloy, J. \& Bellocq, M. I. 2009. Bird community responses along urban-rural gradients: does the size of the urbanized area matter? - Landscape and Urban Planning 90(1-2): 33-41. DOI: 10.1016/j.landurbplan.2008.10.004.

Grimmett, R., Inskipp, C. \& Inskipp, T. 2016. Birds of the Indian Subcontinent: India, Pakistan, Sri Lanka, Nepal, Bhutan, Bangladesh and the Maldives. - Bloomsbury Publishing

Hansen, A. J. \& Urban, D. L. 1992. Avian response to landscape pattern: the role of species' life histories. - Landscape Ecology 7(3): 163-180. DOI: 10.1007/BF00133308.

Hensley, C. B., Trisos, C. H., Warren, P. S., MacFarland, J., Blumenshine, S., Reece, J. \& Katti, M. 2019. Effects of urbanization on bird assemblages in three southwestern US cities. - Frontiers in Ecology and Evolution 7: 71. DOI: $10.3389 /$ fevo.2019.00071

Hostetler, M. 2001. The importance of multi-scale analyses in avian habitat selection studies in urban environments. - In: Marzluff, J. M., Bowman, R. \& Donnelly, R. (eds.) Avian Ecology and Conservation in an Urbanizing World. - Springer, Boston, MA. DOI: 10.1007/978-1-4615-1531-9_7

Jongman, R., Braak, C. \& Van Tongeren, O. 1995. Data Analysis in Community and Landscape Ecology. - Cambridge University Press, Cambridge, UK. DOI: $10.2307 / 2531665$

Joshua, G. \& Ali, Z. 2011. Avian diversity with the varying urban congestions of Lahore. - Journal of Animal and Plant Sciences 21(4): 21-482.

Katuwal, H. B., Pradhan, N. M. B., Thakuri, J. J., Bhusal, K. P., Aryal, P. C. \& Thapa, I. 2018. Effect of urbanization and seasonality in bird communities of Kathmandu Valley, Nepal. - Proceedings of the Zoological Society 71: 103-113. DOI: 10.1007/s12595-018-0265-Z

Kent, M. \& Coker, P. 1992. Vegetation Description and Analysis: A Practical Approach. - Belven Press, London. DOI: $10.2307 / 3451427$

Khan, H. A., Beg, M. A. \& Khan, A. A. 2004. Breeding habitats of the Rose-ringed Parakeet (Psittacula krameri) in the cultivations of Central Punjab. - Pakistan Journal of Zoology 36: 133-138.

Khan, M. Z., Tabbassum, F., Ghalib, S. A., Zehra, A., Hussain, B., Siddiqui, S., Yasmeen, G., Gabol, K., Mahmood, N. \& Khan, I. S. 2014. Distribution population status and conservation of the birds in Karachi Sindh, Pakistan. - Canadian Journal of Pure and Applied Sciences 8(1): 2697-2713. DOI: 10.6000/19275129.2012.08.01.05.

Kler, T. 2009. Some observations on the breeding activities of the Pied Myna Sturnus contra (Linn.). - Environment and Ecology 27(1): 213-215.

Kluza, D. A., Griffin, C. R. \& DeGraaf, R. M. 2000. Housing developments in rural New England: effects on forest birds. - Animal Conservation Forum 3: 15-26. DOI: 10.1111/j.1469-1795.2000.tb00083.x.

Lancaster, R. K. \& Rees, W. E. 1979. Bird communities and the structure of urban habitats. - Canadian Journal of Zoology 57(12): 2358-2368. DOI: 10.1139/z79-307

Leveau, L. M. \& Leveau, C. M. 2016. Does urbanization affect the seasonal dynamics of bird communities in urban parks? - Urban Ecosystems 19(2): 631-647. DOI: 10.1007/s11252-016-0525-5.

Lim, H. C. \& Sodhi, N. S. 2004. Responses of avian guilds to urbanisation in a tropical city. - Landscape and Urban Planning 66(4): 199-215. DOI: 10.1016/S0169-2046(03)00111-7.

Loyola, R. D. \& Martins, R. P. 2008. Habitat structure components are effective predictors of trap-nesting Hymenoptera diversity. - Basic and Applied Ecology 9(6): 735-742. DOI: 10.1016/j.baae.2007.06.016 
Luck, G. W. \& Smallbone, L. T. 2010. Species diversity and urbanisation: patterns, drivers and implications. - In: Kevin, J. G. (ed.) Urban Ecology. - Cambridge University Press, pp. 88-119. DOI: 10.1017/ CBO9780511778483.006.

Machtans, C. S. \& Latour, P. B. 2003. Boreal forest songbird communities of the Liard Valley, northwest territories, Canada. - The Condor 105(1): 27-44. DOI: 10.1093/condor/105.1.

Manjula, M., Mohanraj, R. \& Devi, M. P. 2015. Biomonitoring of heavy metals in feathers of eleven common bird species in urban and rural environments of Tiruchirappalli, India. - Environmental Monitoring and Assessment 187(5): 4502. DOI: 10.1007/s10661-015-4502-x.

Marzluff, J. M. \& Ewing, K. 2001. Restoration of fragmented landscapes for the conservation of birds: a general framework and specific recommendations for urbanizing landscapes. - Restoration Ecology 9(3): 280-292. DOI: $10.1046 / j .1526-100 x .2001 .009003280 . x$

McKinney, M. L. 2002. Urbanization, biodiversity and conservation. The impacts of urbanization on native species are poorly studied, but educating a highly urbanized human population about these impacts can greatly improve species conservation in all ecosystems. - BioScience 52(10): 883-890. DOI: 10.1641/0006-3568(2002)052[0883:UBAC]

McKinney, M. L. 2006. Urbanization as a major cause of biotic homogenization. - Biological Conservation 127(3): 247-260. DOI: 10.1016/j.biocon.2005.09.005

McKinney, M. L. 2008. Effects of urbanization on species richness: a review of plants and animals. - Urban Ecosystems 11(2): 161-176. DOI: 10.1007/s11252-007-0045-4.

Mehmood, H., Sajjad, S. \& Shirazi, S. 2017. Spatio-temporal trends and patterns of urban sprawl in Gujranwala city, Punjab, Pakistan. - Pakistan Journal of Science 69(1): 63-68.

Melles, S., Glenn, S. \& Martin, K. 2003. Urban bird diversity and landscape complexity: species-environment associations along a multiscale habitat gradient. - Conservation Ecology 7(1): 5. DOI: 10.5751/ES-00478070105

Mills, G. S., Dunning, Jr. J. B. \& Bates, J. M. 1989. Effects of urbanization on breeding bird community structure in southwestern desert habitats. - The Condor 91(2): 416-428._DOI: 10.2307/1368320.

Ortega-Álvarez, R. \& MacGregor-Fors, I. 2009. Living in the big city: Effects of urban land-use on bird community structure, diversity, and composition. - Landscape and Urban Planning 90(3-4): 189-195. DOI: 10.1016/j.landurbplan.2008.11.003

Parsons, H., Major, R. E. \& French, K. 2006. Species interactions and habitat associations of birds inhabiting urban areas of Sydney, Australia. - Austral Ecology 31(2): 217-227. DOI: 10.1111/j.1442-9993.2006.01584.x

Pattnaik, P., Das, M. \& Parida, S. P. 2016. Preliminary study of avifauna diversity of Utkal University Campus, Bhubaneswar, Odisha, India. - Current Life Sciences 2(1): 20-26.

Peacock, D. S., van Rensburg, B. J. \& Robertson, M. P. 2007. The distribution and spread of the invasive alien Common Myna, Acridotheres tristis L. (Aves: Sturnidae), in southern Africa. - South African Journal of Science 103(11-12): 465-473.

Peck, H. L., Pringle, H. E., Marshall, H. H., Owens, I. P. \& Lord, A. M. 2014. Experimental evidence of impacts of an invasive parakeet on foraging behavior of native birds. - Behavioral Ecology 25(3): 582-590. DOI: 10.1093/beheco/aru025.

Peh, K. S-H. 2010. Invasive species in Southeast Asia: the knowledge so far. - Biodiversity and Conservation 19(4): 1083-1099. DOI: 10.1007/s10531-009-9624-4.

Poulsen, B. O. 2002. Avian richness and abundance in temperate Danish forests: tree variables important to birds and their conservation. - Biodiversity \& Conservation 11(9): 1551-1566. DOI: 10.1023/A:1016839518172

Rajashekara, S. \& Venkatesha, M. 2014. Insectivorous bird communities of diverse agro-ecosystems in the Bengaluru region, India. - Journal of Entomology and Zoology Studies 2(5): 142-155.

Rottenborn, S. C. 1999. Predicting the impacts of urbanization on riparian bird communities. Biological Conservation 88(3): 289-299. DOI: 10.1016/S0006-3207(98)00128-1

Sekercioglu, C. H. 2012. Bird functional diversity and ecosystem services in tropical forests, agroforests and agricultural areas. - Journal of Ornithology 153(1): 153-161. DOI: 10.1007/s10336-012-0869-4

Seress, G. \& Liker, A. 2015. Habitat urbanization and its effects on birds. - Acta Zoologica Academiae Scientiarum Hungaricae 61(4): 373-408. DOI: 10.1007/s10336-012-0869-4

Sergio, F., Pedrini, P. \& Marchesi, L. 2003. Adaptive selection of foraging and nesting habitat by Black Kites (Milvus migrans) and its implications for conservation: a multi-scale approach. - Biological Conservation 112(3): 351-362. DOI: 10.1016/S0006-3207(02)00332-4. 
Shochat, E., Lerman, S. \& Fernández-Juricic, E. 2010. Birds in urban ecosystems: population dynamics, community structure, biodiversity, and conservation. - Urban Ecosystem Ecology 55(2010): 75-86. DOI: 10.2134/ agronmonogr55.c4

Sol, D., González-Lagos, C., Lapiedra, O. \& Díaz, M. 2017. Why are exotic birds so successful in urbanized environments? - In: Murgui, E. \& Hedblom, M. (ed.) Ecology and Conservation of Birds in Urban Environments. - Springer, pp. 75-89. DOI: 10.1007/978-3-319-43314-1_5. 75.

Tiwary, N. \& Urfi, A. 2016. Spatial variations of bird occupancy in Delhi: The significance of woodland habitat patches in urban centres. - Urban Forestry \& Urban Greening 20(3): 38-347. DOI: 10.1016/j.ufug.2016.10.002

Trammell, E. J. \& Bassett, S. 2012. Impact of urban structure on avian diversity along the Truckee River, USA. Urban Ecosystems 15(4): 993-1013. DOI: 10.1007/s11252-012-0251-6.

van Rensburg, B. J., Peacock, D. S. \& Robertson, M. P. 2009. Biotic homogenization and alien bird species along an urban gradient in South Africa. - Landscape and Urban Planning 92(3-4): 233-241. DOI: 10.1016/j.landurbplan.2009.05.002.

Villegas, M. \& Garitano-Zavala, Á. 2010. Bird community responses to different urban conditions in La Paz, Bolivia. - Urban Ecosystems 13(3): 375-391. DOI: 10.1007/s11252-010-0126-7.

White, J. G., Antos, M. J., Fitzsimons, J. A. \& Palmer, G. C. 2005. Non-uniform bird assemblages in urban environments: the influence of streetscape vegetation. - Landscape and Urban Planning 71(2-4): 123-135. DOI: 10.1016/j.landurbplan.2004.02.006.

Yap, C. A. \& Sodhi, N. S. 2004. Southeast Asian invasive birds: ecology, impact and management. - Ornithological Science 3(1): 57-67. DOI: 10.2326/osj.3.57

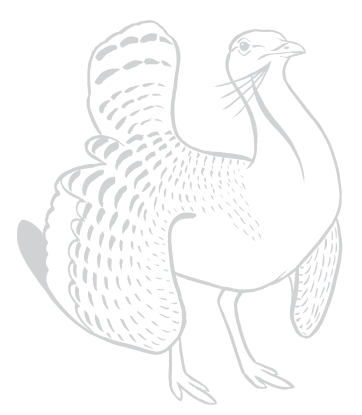

